\title{
Pengaruh Kinerja Lingkungan pada Nilai Perusahaan dengan Good Corporate Governance Sebagai Variabel Pemoderasi
}

\author{
I Made Edi Wijaya Kusuma ${ }^{1}$ \\ Luh Gede Krisna Dewi ${ }^{2}$ \\ ${ }^{1,2}$ Fakultas Ekonomi dan Bisnis Universitas Udayana (Unud), Bali, Indonesia \\ e-mail: ediwijayakusuma12345@gmail.com
}

\begin{abstract}
ABSTRAK
Sampel yang diambil 35 perusahaan dengan tahun pengamatan 5 tahun sehingga didapatkan jumlah sampel sebanyak 175, dengan menggunakan teknik purposive sampling. Teknik analisis yang digunakan adalah Moderated Regression Analysis (RMA). Berdasarkan hasil analisis ditemukan bahwa kinerja lingkungan berpengaruh signifikan pada nilai perusahaan. Hal ini menunjukan bahwa semakin bagus atau baik kinerja lingkungan yang dilakukan perusahaan akan dapat menarik para investor untuk berinvestasi karena telah mendapatkan kepercayaan dari masyarakat sehingga hal ini dapat meningkatkan nilai perusahaan. Dan Good Corporate Governance yang diproksikan sebagai Dewan Komisaris Independen dapat memperkuat pengaruh Kinerja Lingkungan terhadap Nilai Perusahaan karena semakin tinggi proporsi dewan komisaris independen maka semakin ketat monitoring yang dilakukan dewan komisaris independen dalam meningkatkan kinerja perusahaan. Sehingga hal ini dapat meningkatkan nilai perusahaan
\end{abstract}

Kata kunci: Kinerja lingkungan, nilai perusahaan, good corporate governance

\begin{abstract}
The sample was taken by 35 companies with 5 years observation year so that the sample number was 175, using purposive sampling technique. The analysis technique used is Moderated Regression Analysis (RMA). Based on the results of the analysis it was found that environmental performance had a significant effect on the value of the company. This shows that the better or better the environmental performance of the company will be able to attract investors to invest because it has gained trust from the community so that this can increase the value of the company. And Good Corporate Governance, which is proxied as an Independent Board of Commissioners, can strengthen the influence of Environmental Performance on Corporate Values because the higher the proportion of independent commissioners, the more rigorous monitoring by independent board of commissioners in improving company performance. So that this can increase the value of the company.

Keywords: Environmental performance, company value, good corporate governance
\end{abstract}

\section{PENDAHULUAN}

Era globalisasi ditandai dengan banyaknya perusahaan yang mengembangkan usahanya, perusahaan sendiri didefinisikan sebagai suatu organisasi yang didirikan perorangan, sekelompok orang maupun badan lain. Perusahaan melakukan kegiatan berupa produksi bertujuan untuk memenuhi kebutuhan 
ekonomis manusia (Sumarsono, 2004). Salah satu jenis perushaan adalah perusahaan manufaktur. Perusahaan manufaktur mengalami proses yang panjang mulai dari mengolah bahan mentah menjadi bahan jadi bertujuan untuk memaksimalkan nilai perusahaan yang nantinya akan baik atau tidaknya perusahaan tersebut di masa mendatang. Hal ini menjadi acuan para pemegang saham untuk menempatkan modalnya di perusahaan tersebut.

Naik turunnya nilai perusahaan dapat dilihat dari harga sahamnya. Umumnya setiap perusahaan memiliki tujuan yang sama yaitu meningkatkan nilai perusahaan, memaksimalkan kekayaan pemilih perusahaan atau para pemegang saham, dan memaksimalkan nilai perusahaan(Danarwati, 2013). Perusahaan yang memiliki tingkat nilai perusahaan yang tinggi, dianggap dapat menarik para investor untuk menanam modalnya diperusahaan tersebut. Harga pasar saham bertindak sebagai barometer kinerja manajemen perusahaan. Ketidakstabilan harga saham menyulitkan investor dalam melakukan investasi. Investor tidak sembarangan dalam melakukan investasi atas dana yang dimilikinya, terlebih dahulu mereka harus mempertimbangkan berbagai informasi.

Informasi tentang penurunan harga saham perusahaan dapat disebabkan karena kasus-kasus dalam perusahaan. Contoh kasus pencemaran lingkungan oleh perusahaan manufaktur pernah terjadi di daerah Banyuwangi, Jawa Timur. Kondisi alam kabupaten Banyuwangi yang subur dan kondisi sungai yang hampir tidak pernah kering serta dekat dengan laut memungkinkan daerah ini berkembang beberapa industri yang mengandalkan sumber daya alam, salah satu diantaranya adalah kertas. PT. Kertas Basuki Rachmat sebagai industri kertas di 
kabupaten Banyuwangi telah mampu meningkatkan perekonomian masyarakat dan membawa keuntungan finansial bagi masyarakat, pemerintah kabupaten, pemerintah provinsi maupun pusat. Akan tetapi pendirian industri ternyata tidak saja membawa keuntungan finansial namun juga membawa dampak negatif berupa limbah industri yang semakin banyak. Limbah tersebut dapat berwujud gas, cair, dan padat. Hal ini disebabkan oleh peralatan pengolahan limbah yang kurang optimal sehingga lingkungan menjadi tercemar akibat limbah yang dihasilkan oleh perusahaan. Pencemaran terhadap lingkungan ini mengakibatkan gangguan kesehatan masyarakat (Cahyono, 2007).

Bulan Juni tahun 2004, beberapa pabrik kertas yang berada di Jawa Timur masuk dalam daftar merah atau buruk dalam memenuhi kriteria baku mutu buangan limbah cair. Berdasarkan Keputusan Menteri Lingkungan Hidup No. 228 tahun 2005, PT. Kertas Basuki Rachmat menjadi industri yang masuk dalam nomor 53 peringkat hitam dalam program pentaatan industri dalam pengelolaan lingkungan (PROPER) yang artinya perusahaan tidak mempunyai kepedulian sama sekali terhadap lingkungan sehingga dikenakan sanksi atas pencemaran yang dilakukan (KLH, 2005). Permasalahan lingkungan yang ditimbulkan oleh perusahaan akhirnya akan berdampak terhadap citra perusahaan di mata investor dan masyarakat sekitar.

Terdapat beberapa faktor yang dapat mempengaruhi nilai perusahaan, salah satunya adalah kinerja lingkungan. Menurut(Suratno, Darsono, \& Mutmainah, 2006), kinerja lingkungan perusahaan (environmental performance) adalah kinerja perusahaan dalam menciptakan lingkungan yang baik (green). 
Perusahaan perlu menyediakan informasi bagi pemegang saham serta stakeholder lain atas aktivitas bisnis perusahaan yang mempengaruhi lingkungan sekitar, maka diperlukan informasi lengkap dan menyeluruh mengenai corporate sustainability untuk mewujutkan kinerja perusahaan yang baik. Informasi tersebut disediakan oleh akuntansi lingkungan, dimana merupakan proses identifikasi semua sumber daya yang digunakan serta manfaat dari penggunaan sumber daya atas aktivitas perusahaan melestarikan lingkungan dalam beroperasi secara rutin (Hernadi, 2012).

Terkait dengan teori legitimasi, kinerja lingkungan yang baik harus dimiliki perusahaan sebagai upaya mewujudkan organisasi yang peduli terhadap lingkungan sekitar. Kepedulian suatu perusahaan terhadap lingkungan dapat dipengaruhi oleh keluhan konsumen dan tuntutan stakeholders. Mereka belum menyadari bahwa masalah lingkungan tidak hanya memerlukan tuntutan dari luar, tetapi seharusnya menjadi tindakan proaktif. Di beberapa negara industri, perusahaan-perusahaan sudah menyadari pentingnya kesadaran terhadap lingkungan dengan mengurangi tingkat polusi dan meningkatkan profit secara simultan. Akar permasalahan dalam kerusakan lingkungan adalah pertumbuhan penduduk yang sangat pesat, pertumbuhan ekonomi yang cepat dan pada saat yang sama pertumbuhan industri cukup pesat yang diikuti dengan penyalahgunaan sumber daya alam, penggunaan teknologi pada hampir setiap perusahaan serta keinginan untuk mengikuti globalisasi.

Semakin banyak sektor industri pengolahan maka semakin meningkat aktivitas industri, khususnya industri manufaktur. Akibatnya akan berdampak 
pada masalah-masalah lingkungan, seperti polusi udara, polusi air dan polusi suara. Terjadinya pencemaran muncul karena kegiatan yang sengaja maupun tidak sengaja. Selain itu, pencemaran udara dan air dapat disebabkan oleh kegiatan manusia ataupun alam yang dapat menyebabkan menurunnya fungsi air dan udara. Fenomena ini tentunya berpengaruh terhadap keberlangsungan perusahaan sehingga permasalahan lingkungan perlu mendapatkan perhatian yang tinggi.

Masyarakat sekarang lebih pintar dan memilih produk yang akan mereka konsumsi. Sekarang, masyarakat cenderung untuk memilih produk yang diproduksi peduli terhadap lingkungan. Survei yang dilakukan Booth-Harris Trust Monitor pada tahun 2001 dalam (Sutopoyudo, 2009), menunjukkan bahwa mayoritas konsumen akan meninggalkan suatu produk yang mempunyai citra buruk atau diberitakan negatif. (Pflieger, Fischer, Kupfer, \& Eyerer, 2015), menjelaskan bahwa kegiatan perusahaan dalam bidang pelestarian lingkungan akan mendatangkan keuntungan, diantaranya ketertarikan pemegang saham dan stakeholder terhadap keuntungan perusahaan akibat pengelolaan lingkungan yang bertanggung jawab. Perusahaan yang mempunyai kinerja lingkungan yang baik akan semakin disukai oleh konsumen dan diminati oleh investor, sehingga nilai perusahaan semakin meningkat. Berkembangnya konsep ekoefisiensi mendorong perusahaan untuk mencapai kinerja keuangan dan kinerja lingkungan secara simultan.

Terkait isu permasalahan yang disebabkan oleh perusahaan di Indonesia, pemerintah mengeluarkan kebijakan tentang pelestarian lingkungan yang diatur dalam Undang-Undang No. 40 Tahun 2007 tentang Perseroan Terbatas (UUPT) 
serta Peraturan Pemerintah No. 47 Tahun 2012 tentang Tanggung Jawab Sosial dan Lingkungan Perseroan Terbatas. Tahun 2002, Kementerian Lingkungan Hidup telah mengadakan Program Penilaian Peringkat Kinerja Perusahaan (PROPER) bertujuan untuk meningkatkan peran perusahaan dalam melaksanakan pengelolaan lingkungan hidup. Dalam PROPER ini, kinerja lingkungan perusahaan dapat dinilai dari peringkat warna yang terbaik emas, hijau, biru, merah hingga yang terburuk yaitu hitam. Hasil evaluasi ini akan diumumkan dengan rutin kepada masyarakat.

Konsep Good Corporate Governance merupakan konsep yang sudah saatnya untuk diterapkan dalam perusahaan-perusahaan yang terdapat di Indonesia, karena melalui konsep yang terkait dengan struktur perseroan, yang terdiri atas unsur-unsur Rapat Umum Pemegang Saham (RUPS) dan direksi komisaris, dapat terjalin hubungan dan mekanisme kerja, pembagian kerja, pembagian tugas, kewenangan dan tanggung jawab yang harmonis, baik secara intern maupun ekstern, yang bertujuan untuk meningkatkan nilai perusahaan demi kepentingan shareholders dan stakeholders. Penelitian ini, indikator mekanisme Good Corporate Governance yang digunakan yaitu dewan komisaris independen. Dewan komisaris independen diharapkan mampu menjalankan tugas pengawasan yang lebih efektif serta memberikan nilai tambah bagi suatu perusahaan dan dapat memastikan bahwa manajemen benar-benar bekerja demi meningkatkan kinerja perusahaan. Adanya peningkatan kinerja di dalam suatu perusahaan, maka nilai perusahaan tersebut akan menjadi lebih baik. 
Penelitian dengan hasil yang beragam menyatakan terkait hubungan pengaruh kinerja lingkungan pada nilai perusahaan, menurut Hariati dan Rihatiningtyas (2015), Dewi dan Wirasedana (2017), dan (Arieftiara \& Venusita, 2017) menyatakan kinerja lingkungan berpengaruh positif terhadap nilai perusahaan. Apabila perusahaan manufaktur mampu memperhatikan pengelolaan lingkungannya, maka keberadaan perusahaan tersebut akan direspon positif oleh masyarakat, sehingga citra perusahaan meningkat. Investor lebih berminat pada perusahaan yang memiliki citra baik di masyarakat, karena berdampak pada tingginya loyalitas konsumen terhadap produk perusahaan. Dengan demikian, dalam jangka panjang penjualan dan profitabilitas perusahaan akan meningkat. Semakin tinggi profitabilitas perusahaan, maka semakin besar pula return yang diterima sehingga akan berdampak pada peningkatan nilai perusahaan.

Menurut (Ardila, 2017) dan (Sawitri, 2017) menyatakan bahwa kinerja lingkungan tidak berpengaruh signifikan terhadap nilai perusahaan karena tidak semua investor melihat kinerja sebagai kriteria berinvestasi. Bagi investor, kinerja lingkungan yang baik belum menjamin suatu perusahaan dapat memberikan keuntungan bagi investor. Selain itu, bagi investor pengolahan lingkungan akan menambah biaya yang akan dikeluarkan oleh perusahaan sehingga nanti dapat mempengaruhi pendapatan investor.

Penelitian ini menganalis perusahaan manufaktur yang terdaftar di Bursa Efek Indonesia. Perusahaan manufaktur dipilih sebagai populasi penelitian ini karena perusahaan manufaktur yang terdaftar di Bursa Efek Indonesia merupakan kelompok sektor yang memiliki jumlah perusahaan terbesar dibandingkan dengan 
sektor lainnya. Selain itu sektor manufaktur merupakan sektor yang dalam aktivitas operasinya menghasilkan limbah. Limbah tersebut apabila tidak dikelola secara baik akan berdampak buruk terhadap lingkungan, oleh karena itu perlu langkah yang bijak oleh perusahaan dalam mengatasi limbahnya sehingga tidak berdampak negatif terhadap lingkungan sekitar.

Teori sinyal adalah teori yang menjelaskan suatu tindakan yang dilakukan manajemen perusahaan dengan memberikan suatu petunjuk atau sinyal kepada stakeholders. Isyarat atau signal adalah tindakan yang diambil perusahaan untuk memberi arahan kepada investor tentang bagaimana manajemen memandang prospek perusahaan. Sinyal dapat berupa promosi atau informasi lain yang menyatakan bahwa perusahaan tersebut lebih baik daripada perusahaan lain(Budiharjo, 2016). Selain itu, perusahaan yang memiliki nilai yang tinggi cenderung memiliki laporan yang mudah dibaca dan dapat dibedakan dari perusahaan lainnya(Birjandi \& Sadeghi, 2015). Informasi yang dikeluarkan oleh perusahaan merupakan hal yang penting bagi stakeholders dan pelaku bisnis. Dengan adanya informasi, stakeholders dan pelaku bisnis dapat mengetahui kondisi yang terjadi dalam perusahaan yang akan dijadikan dasar dalam pengambilan keputusan. Asimetri informasi akan terjadi ketika manajer lebih mengetahui informasi internal dan prospek perusahaan di masa yang akan datang dibandingkan dengan pemilik dan stakeholders lainnya(Barus dan Setiawati, 2015). Morris (1987) menyatakan, perusahaan lebih banyak memiliki informasi mengenai produk yang dijualnya dari pada pembeli. Apabila pembeli tidak memiliki informasi yang cukup lengkap maka cara pandangan pembeli dalam 
menilai semua produk dengan harga yang sama. Kurangnya informasi mengenai perusahaan menyebabkan mereka memberikan harga yang rendah untuk perusahaan. Perusahaan dapat meningkatkan nilai perusahaan dengan mengurangi asimetri informasi.

Hubungan teori sinyal dalam penelitian ini adalah perusahaaan dapat memberikan sinyal pada pihak luar yang memiliki kepentingan terhadap perusahaan tesebut akan dapat mengurangi asimetri informasi yang dimilikinya. Tentunya dengan berkurangnya asimetri informasi, perusahaan tersebut dapat memberi informasi yang jelas mengenai prospek perusahaan yang baik dari perusahaan lainnya. Investor akan dapat menerima sinyal yang diberikan oleh perusahaan dan dapat menentukan keputusannya dengan sinyal atau informasi yang didapat sehingga akan berpengaruh terhadap nilai perusahaan.

Menurut (Deegan \& Unerman, 2006), Teori Legitimasi menyatakan organisasi secara terus-menerus memastikan bahwa kegiatan operasinya diterima sesuai dengan batasan dan norma oleh masyarakat, sehingga mereka mencoba untuk meyakinkan bahwa aktivitasnya diterima oleh pihak luar. Keberadaan organisasi dapat berlanjut apabila sistem nilai yang digunakan untuk menjalankan kegiatan operasinya sesuai dengan sistem yang dimiliki masyarakat. Kegagalan organisasi dalam memenuhi kontrak sosial dapat menjadi sebuah ancaman bagi kelanjutan usaha tersebut. Ancaman tersebut berupa pembatasan sumber daya (tenaga kerja, bahan baku, modal keuangan) dan juga pencabutan izin usaha. Organisasi akan direspon positif apabila organisasi mampu memenuhi kontrak sosial tersebut dan dengan adanya citra/image positif dari masyarakat diharapkan 
mampu meningkatkan laba organisasi, sehingga dapat meningkatkan nilai perusahaan.

Hubungan Teori Legitmasi dalam penelitian ini adalah perusahaan manufaktur merupakan perusahaan yang aktivitas operasinya mengolah bahan baku atau bahan mentah menjadi barang jadi. Selama proses ini perusahaan akan menghasilkan limbah yang pada umumnya akan berdampak langsung terhadap lingkungan sekitar. Perusahaan tentu ingin tetap eksis dalam aktivitasnya tersebut sehingga untuk mengurangi dampak yang ditimbulkan oleh aktivitasnya perusahaan perlu mengolah atau mengatur limbahnya sehingga tidak berdampak buruk terhadap lingkungan, malah diharapkan semakin memberikan dampak positif terhadap lingkungan. Perusahaan yang mampu mengatasi limbahnya akan dipandang positif oleh masyarakat sehingga eksistensi perusahaan akan tetap berlanjut.

Nilai perusahaan sangat penting karena dengan nilai perusahaan yang tinggi akan diikuti oleh tingginya kemakmuran pemegang saham (Bringham Gapenski, 1996). Nilai perusahaan dikatakan penting karena tingginya nilai perusahaan maka akan diikuti juga tingginya kemakmuran pemegang saham. Semakin tinggi harga saham maka semakin tinggi pula nilai perusahaan. Nilai perusahaan yang tinggi menjadi keinginan bagi para pemilik perusahaan, karena dengan nilai yang tinggi menunjukan kemakmuran pemegang saham juga tinggi.

Menurut (Suratno et al., 2006) ,kinerja lingkungan perusahaan (environmental performance) adalah kinerja perusahaan dalam menciptakan lingkungan yang baik (green). Pengukuran kinerja lingkungan perusahaan di 
Indonesia dapat diukur melalui penilaian yang dilakukan oleh menteri Kementerian Lingkungan Hidup. Penilaian tersebut dinamakan PROPER atau disebut juga Program Penilaian Peringkat Kinerja Perusahaan dalam Pengelolaan Lingkungan Hidup. Program ini dilakukan untuk meningkatkan penataan perusahaan dalam pengelolaan lingkungan hidup dan kepedulian perusahaan dalam bidang manajemen lingkungan yang dapat memberikan nilai tambah bagi perusahaan. Dasar hukum pelaksanaannya PROPER merupakan Keputusan Menteri Negara Lingkungan Hidup Nomor 127 Tahun 2002 yaitu tentang Program Penilaian Peningkatan Kinerja Perusahaan dalam Pengelolaan Lingkungan. Peringkat kinerja lingkungan perusahaan dikelompokan menjadi lima (5) peringkat warna yang bertujuan mempermudah pemegang saham dan stakeholder untuk mengetahui hasil kinerja penataan lingkungan di masingmasing perusahaan.

(Komite Nasional Kebijakan Governance, 2006) menyatakan bahwa setiap perusahaan harus memastikan bahwa Good Corporate Governance diterapkan pada setiap aspek bisnis dan di semua jajaran perusahaan. Menurut (Ernawati, 2010), Good Corporate Governance merupakan seperangkat aturan-aturan yang mengatur hubungan antara pengelola perusahaan, pemegang saham, pemerintah, karyawan, pihak kreditor serta pemegang kepentingan ekstern dan intern lainnya terkait dengan kewajiban dan hak-hak mereka, atau dengan kata lain suatu sistem yang mengendalikan dan mengatur perusahaan untuk menggapai kinerja bisnis yang optimal. Seperti yang dijelaskan di atas dapat disimpulkan bahwa Good Corporate Governance merupakan suatu sistem yang dapat mengendalikan atau 
mengatur pengelolaan perusahaan yang baik. Good Corporate Governance dalam proksi mekanisme terdiri dari Kepemilikan Manajerial, Kepemilikan Institusional, Berdasarkann teori legitimasi merupakan bentuk pengakuan keberadaan perusahaan di masyarakat, perusahaan harus dapat menyelaraskan kepentingan ekonomi dengan kepentingan lingkungan dan sosial. Kepedulian perusahaan dalam bidang manajemen lingkungan dapat memberikan nilai tambah bagi perusahaan. Pfleiger et al., (2005), menjelaskan bahwa kegiatan perusahaan dalam bidang pelestarian lingkungan akan mendatangkan sejumlah keuntungan, diantaranya ketertarikan pemegang saham dan stakeholder terhadap keuntungan bagi suatu perusahaan akibat pengelolaan lingkungan yang bertanggungjawab.

(Figge \& Hahn, 2004), dan (Al-Najjar \& Kalaf, 2012) juga menjelaskan adanya hubungan antara kebijakan lingkungan terhadap nilai perusahaan. Hasil ini konsisten dengan penelitian(Hariati \& Rihatiningtyas, 2015), Dewi dan Wirasedana (2017) dan (Arieftiara \& Venusita, 2017) yang menemukan bahwa adanya pengaruh positif antara kinerja lingkungan terhadap nilai perusahaan sedangkan menurut penelitian (Ardila, 2017) dan (Sawitri, 2017) menemukan bahwa kinerja lingkungan tidak berpengaruh signifikan terhadap nilai perusahaan.

Penemuan tersebut didukung dengan adanya teori legitimasi, yaitu Semakin baik kinerja lingkungan yang dilakukan perusahaan maka citra perusahaan semakin baik dan kepercayaan masyarakat akan meningkat. Perusahaan menginginkan nilai perusahaan meningkat, maka perusahaan harus mampu meningkatkan kinerja/pengelolaan lingkungannya. Pengelolaan lingkungan yang baik akan berdampak terhadap keberlangsungan perusahaan. 
Investor akan tertarik berinvestasi pada perusahaan yang memiliki tanggung jawab terhadap lingkungan yang baik dan memiliki legitimasi masyarakat dapat mempengaruhi keberlangsungan perusahaan untuk kedepannya sehingga kinerja lingkungan berpengaruh terhadap nilai perusahaan.Berdasarkan hal tersebut, maka hipotesis penelitian ini adalah:

$\mathrm{H}_{1}$ : Kinerja Lingkungan berpengaruh positif pada nilai perusahaan.

Kinerja lingkungan perusahaan baik akan memberikan respon positif bagi masyarakat. Didukung dengan teori legitimasi, apabila perusahaan yang memperhatikan lingkungannya dan memiliki citra yang baik akan direspon positif oleh masyarakat. Bagi perusahaan yang taat dalam melakukan pengelolaan lingkungan merupakan salah satu faktor juga yang mendorong investor untuk berinvestasi pada perusahaan dengan kinerja yang baik, sehingga berdampak pada peningkatan nilai perusahaan.Dengan keberadaan dewan komisaris independen dapat memperkuat hubungan antara kinerja lingkungan pada nilai perusahaan

Berdasarkan penelitian yang dilakukan dengan (Hariati \& Rihatiningtyas, 2015), dan Dewi dan Wirasedana (2017) menemukan bahwa dewan komisaris independen berpengaruh positif pada nilai perusahaan sedangkan menurut penelitian yang dilakukan (Prastuti \& Budiasih, 2015) serta (Amanti, 2012) menyatakan bahwa dewan komisaris independen tidak berpengaruh pada nilai perusahaan.

Semakin tinggi proporsi dewan komisaris independen maka semakin ketat pula kegiatan monitoring yang dilakukan, karena fungsi monitoring oleh dewan komisaris independen terhadap berbagai kebijakan yang diambil manajemen 
terkait kepedulian terhadap lingkungan. Pengawasan oleh dewan komisaris independen memberikan nilai tambah bagi suatu perusahaan dan dapat memastikan bahwa manajemen benar-benar bekerja demi meningkatkan kinerja perusahaan. Peningkatan kinerja di dalam suatu perusahaan akan meningkatkan nilai perusahaan tersebut. Semakin tinggi proporsi dewan komisaris independen maka semakin ketat pula monitoring yang dilakukan untuk meningkatkan nilai perusahaan.Berdasarkan hal tersebut, maka hipotesis penelitian ini adalah:

$\mathrm{H}_{2}$ : Good Corporate Governance memperkuat pengaruh kinerja lingkungan pada nilai perusahaan.

\section{METODE PENELITIAN}

Penelitian ini dilakukan pada perusahaan manufaktur yang terdaftar di Bursa Efek Indonesia (BEI) dengan mengakses website www.idx.co.id. Objek dari penelitian ini adalah Nilai Perusahaan. Nilai Perusahaan pada perusahaan manufaktur yang terdaftar di Bursa Efek Indonesia (BEI) periode 2012-2016. Variabel independen atau variabel bebas yang digunakan dalam penelitian ini adalah kinerja lingkungan (X). Variabel dependen atau variabel terikat yang digunakan dalam penelitian ini adalah nilai perusahaan (Y). Variabel pemoderasi yang digunakan dalam penelitian ini adalah Good Corporate Gorvenance yang diproksikan dengan dewan komisaris independen (z).

Data PROPER periode 2012-2016 diperoleh melalui situs www.menlh.go.id. Dalam sistem peringkat kinerja PROPER mencangkup peringkat perusahaan dalam 5 warna yaitu: 
Tabel 1.

Peringkat Kinerja PROPER

\begin{tabular}{ccc}
\hline Warna & Peringkat & Skor \\
\hline Emas & Sangat sangat baik & 5 \\
Hijau & Sangat baik & 4 \\
Biru & Baik & 3 \\
Merah & Buruk & 2 \\
Hitam & Sangat buruk & 1 \\
\hline
\end{tabular}

Sumber: Data diolah, 2018

Pendekatan yang digunakan untuk menghitung PROPER menggunakan skor sesuai dengan peringkat warna PROPER perusahaan, apabila perusahaan dapat peringkat warna tertinggi yaitu emas maka diberi skor 5. Peringkat warna hijau diberi skor 4, peringkat warna biru diberi skor 3, peringkat warna merah diberi skor 2 dan peringkat terendah warna hitam diberi skor 1 .

Dalam penelitian ini yang digunakan untuk mengukur nilai perusahaan adalah dengan menggunakan Tobins'Q model modifikasi versi (Chung \& Pruitt, 1994), dengan rumus :

$$
q=\frac{(M V S+D)}{T A}
$$

Keterangan:

$\begin{array}{ll}\mathrm{q} & : \text { Nilai Perusahaan } \\ \mathrm{MVS} & \text { : Nilai Pasar dari Saham yang Beredar (Closing Price } \\ & \text { Saham x Jumlah Saham Beredar) } \\ \text { D } & \text { : Nilai Pasar Hutang } \\ \text { TA } & \text { Total Aktiva }\end{array}$

Market value of all outstanding shares (MVS) merupakan nilai pasar saham yang diperoleh dari perkalian harga penutupan sahan dengan jumlah saham yang beredar. Debt merupakan besarnya nilai pasar hutang, dimana nilai ini dapat dihitung dengan persamaan berikut:

$$
\mathrm{D}=(\mathrm{AVCL}-\mathrm{AVCA})+\mathrm{AVLD}
$$


Dimana :

AVCL = Accounting value of the firm's Current Liabilities.

= Shot Term Debt + Taxes Payable.

AVLTD = Accounting value of the firm's Long Term Debt.

= Long Term Debt.

AVCA = Accounting value of the firm's Current Asset.

$=$ Cash + Account Recceivable + Inventories .

Dalam penelitian ini Good Corporate Governance sebagai variabel moderator yang diproksikan dengan dewan komisaris independen. Proporsi dapat dihitung dengan cara menghitung anggota dewan komisaris independen yang berasal dari luar perusahaan terhadap seluruh ukuran dewan komisaris (Ernawati, 2010).

$P D K I=\frac{\Sigma D K I}{\Sigma U D K}$

Keterangan:

PDKI : Proporsi dewan komisaris independen

DKI : Jumlah anggota dewan komisaris independen

UDK : Jumlah seluruh ukuran dewan komisaris

Populasi dalam penelitian ini adalah perusahaan manufaktur yang terdaftar di Bursa Efek Indonesia tahun 2012-2016. Sampel yang digunakan dalam penelitian ini adalah perusahaan manufaktur yang terdaftar di BEI tahun 20122016 yang telah dipilih dengan menggunakan teknik purposive sampling.

Teknik analisis data yang digunakan untuk memecahkan permasalahan dalam penelitian ini adalah Moderated Regression Anayisis (MRA) dengan menggunakan SPSS versi 22 untuk menganalisis perhitungan data. Dalam penelitian ini menggunakan Moderated Regression Analysis (MRA) bertujuan untuk mengetahui Pengaruh Kinerja Lingkungan pada Nilai Perusahaan dengan 
Good Corporate Governance yang memoderasi hubungan kinerja lingkungan dengan Nilai Perusahaan. Moderated Regression Analysis (MRA) dapat dihitung dengan persamaan sebagai berikut:

$$
\mathrm{Y}=\alpha+\beta_{1} \mathrm{X}_{1}+\beta_{2} \mathrm{X}_{1}^{*} \mathrm{Z}+\mathrm{e}
$$

Keterangan :

$$
\begin{array}{ll}
\alpha & =\text { Konstanta } \\
\beta_{1-} \beta_{3} & =\text { Koefisien Regresi } \\
\mathrm{Y} & =\text { Nilai Perusahaan } \\
\mathrm{X}_{1} & =\text { Kinerja Lingkungan } \\
\mathrm{X}_{1} \mathrm{Z} & =\text { Interaksi antara Kinerja Lingkungan dengan Good } \\
& \text { Corporate Governance } \\
\mathrm{e} & =\text { error atau variabel pengganggu }
\end{array}
$$

\section{HASIL DAN PEMBAHASAN}

Uji statistik deskriptif adalah sesuatu uji yang dilakukan untuk menilai karakteristik suatu kumpulan data. Karakteristik-karakteristik yang dinilai adalah rata-rata (mean), nilai minimum, nilai maksimum dan standar devisiasi pada kumpulan data tersebut. Rata-rata (mean) merupakan nilai tengah yang terdapat pada kumpulan data. Nilai minimum dan maksimum merupakan niliai terendah dan nilai tertinggi yang terdapat pada suatu kumpulan data. Standar deviasi merupakan suatu ukuran untuk menilai tingkat variasi nilai suatu kumpulan data. Hasil uji deskriptif pada penelitian ini selanjutnya akan disajikan pada Tabel 2 sebagai berikut: 
Tabel 2.

Hasil Uji Statistik Deskritif

\begin{tabular}{lcrrrr}
\hline & N & \multicolumn{1}{c}{ Minimum } & \multicolumn{1}{c}{ Maximum } & \multicolumn{1}{c}{ Mean } & Std. Deviation \\
\hline Kinerja & 175 & 2,00 & 5,00 & 3,097 & 0,658 \\
Lingkungan & 175 & 0,20 & 0,80 & 0,391 & 0,108 \\
GCG & 175 & $-0,24$ & 18,18 & 22,891 & 3,434 \\
Nilai Perusahaan & 175 & & & & \\
Valid N (listwise) & \multicolumn{5}{l}{ Sumber: Data Diolah, 2018 }
\end{tabular}

Sumber: Data Diolah, 2018

Rata-rata variabel Kinerja Lingkungan $(\mathrm{X})$ perusahaan selama lima tahun periode penelitian sebesar 3,097 dan nilai standar deviasi sebesar 0,658 yang lebih rendah dari nilai rata-rata menunjukan bahwa terdapat variasi variabel kinerja lingkungan yang kecil antara nilai minimum dan nilai maksimum. Nilai minimum dan maksimum kinerja lingkungan selama lima tahun periode penelitian masingmasing sebesar 2,00 dan 5,00.

Rata-rata variabel Good Corporate Governance (Z) perusahaan selama lima tahun periode penelitian sebesar 0,391 dan nilai standar deviasi sebesar 0,108 yang lebih rendah dari nilai rata-rata menunjukan bahwa terdapat variasi variabel Good Corporate Governanceyang kecil antara nilai minimum dan nilai maksimum. Nilai minimum dan maksimum Good Corporate Governanceselama lima tahun periode penelitian masing-masing sebesar 0,20 dan 0,80 .

Rata-rata variabel Nilai Perusahaan (Y) perusahaan selama lima tahun periode penelitian sebesar 22,891 dan nilai standar deviasi sebesar 3,434 yang lebih rendah dari nilai rata-rata menunjukan bahwa terdapat variasi variabel Nilai Perusahaan yang kecil antara nilai minimum dan nilai maksimum. Nilai minimum dan maksimum Nilai Perusahaan selama lima tahun periode penelitian masingmasing sebesar -0,24 dan 18,18.Nilai perusahaan terendah dimiliki oleh Jaya Pari Stell Tbk sebesar -0,24 mencerminkan bahwa nilai Tobins's Q kurang dari satu 
dimana perusahaan tersebut telah gagal dalam mengelola aktiva perusahaannya dan memiliki prospek perusahaan yang kurang baik. Hal ini perlu menjadi perhatian khusus karena harga saham perusahaan tersebut relatif kurang diminati pasar. Sedangkan nilai tertinggi dimiliki oleh Unilever Indonesia Tbk sebesar 18,18 mencerminkan bahwa nilai Tobin's Q lebih dari satu merupakan sinyal yang baik bagi pasar karena perusahaan telah berhasil dalam mengelola perusahaannya dan memiliki prospek perusahaan yang baik.

Hasil analisis uji interaksi dengan menggunakan program SPSS dapat dilihat pada tabel 3 .

Tabel 3.

Hasil Uji Interaksi (Moderated Regression Analysis)

\begin{tabular}{|c|c|c|c|c|c|c|c|}
\hline \multirow{2}{*}{\multicolumn{2}{|c|}{ Model }} & \multicolumn{3}{|c|}{ Unstandardized Coefficients } & \multirow{2}{*}{$\begin{array}{c}\text { Standardized } \\
\text { Coefficients } \\
\text { Beta } \\
\end{array}$} & \multirow{2}{*}{$\mathrm{T}$} & \multirow{2}{*}{ Sig. } \\
\hline & & $\mathrm{B}$ & & $\begin{array}{l}\text { Std. } \\
\text { Error }\end{array}$ & & & \\
\hline \multirow{4}{*}{1} & (Constant) & & 0,551 & 0,04 & & 13,786 & 0 \\
\hline & $\begin{array}{l}\text { Kinerja } \\
\text { Lingkungan }\end{array}$ & & 0,283 & 0,14 & 0,516 & 2,018 & 0,045 \\
\hline & GCG & & 0,286 & 0,204 & 0,52 & 1,402 & 0,163 \\
\hline & $\begin{array}{l}\text { Interaksi } \\
\text { X.Z }\end{array}$ & & 0,581 & 0,272 & 1,057 & 2,137 & 0,034 \\
\hline \multirow{4}{*}{\multicolumn{2}{|c|}{$\begin{array}{l}\text { R Square } \\
\text { Adjusted R Square } \\
\text { F Hitung } \\
\text { Signifikansi F }\end{array}$}} & & & & & & 0,091 \\
\hline & & & & & & & 0,075 \\
\hline & & & & & & & 5,681 \\
\hline & & & & & & & 0,001 \\
\hline
\end{tabular}

Berdasarkan hasil analisis regresi linier berganda seperti yang disajikan pada Tabel 3, maka persamaan strukturalnya adalah sebagai berikut :

$$
Y=0,551+0,283 X+0,286 Z+0,581 X Z
$$

Nilai Konstanta $(\alpha)$ sebesar 0,551 memiliki arti bahwa apabila kinerja lingkungan, good corporate governance, dan hubungan antara kinerja lingkungan 
dengan good corporate governance memiliki nilai konstanta pada angka nol, maka nilai perusahaan sebesar 0,551 .

Nilai koefisiensi regresi variabel kinerja lingkungan memiliki nilai sebesar 0,283. Nilai koefisien regresi yang bernilai positif mempunyai arti apabila kinerja lingkungan meningkat satu satuan, maka nilai perusahaan akan meningkat sebesar 0,283 satuan dengan asumsi variabel lainnya konstan.

Nilai koefisiensi regresi variabel good corporate governance memiliki nilai sebesar 0,286 . Nilai koefisien regresi yang bernilai positif mempunyai arti apabila good corporate governance meningkat satu satuan, maka nilai perusahaan akan meningkat sebesar 0,286 satuan dengan asumsi variabel lainnya konstan.

Nilai koefisiensi regresi moderat antara kinerja lingkungan good corporate governance memiliki nilai sebesar 0,581 . Nilai koefisien regresi yang bernilai positif mempunyai arti apabila setiap interaksi kinerja lingkungan dengan good corporate governance meningkat satu satuan, maka nilai perusahaan akan meningkat sebesar 0,581 satuan dengan asumsi variabel lainnya konstan.

Uji kesesuaian model regresi bertujuan untuk mengetahui apakah semua variabel bebas yang diidentifikasi (kinerja lingkungan, GCG dan variabel interaksi antara GCG dengan kinerja lingkungan) tepat digunakan memprediksi Earnings Management. Uji ini sering juga disebut dengan uji F.

Tabel 4. Hasil Uji F

\begin{tabular}{|c|c|c|c|c|c|c|c|}
\hline Model & & & $\begin{array}{l}\text { Sum of } \\
\text { Squares }\end{array}$ & Df & $\begin{array}{l}\text { Mean } \\
\text { Square }\end{array}$ & $\mathrm{F}$ & Sig. \\
\hline & \multirow{3}{*}{1} & Regression & 4,764 & 3 & 1,588 & 5,681 & $0,001^{\mathrm{a}}$ \\
\hline & & Residual & 47,799 & 171 & 0,280 & & \\
\hline & & Total & 52,563 & 174 & & & \\
\hline
\end{tabular}

Sumber: Data diolah, 2018 
Hasil uji $\mathrm{F}$ (Ftest) menunjukkan bahwa nilai signifikansi $\mathrm{P}$ value 0,001 yang lebih kecil dari $\alpha=0,05$, ini berarti model yang digunakan pada penelitian ini adalah layak. Hasil ini memberikan makna bahwa seluruh variabel independen yaitu kinerja lingkungan, GCG dan variabel interaksi antara GCG dengan kinerja lingkungan mampu memprediksi atau menjelaskan fenomena nilai perusahaan pada seluruh sampel perusahaan manufaktur yang terdaftar di Bursa Efek Indonesia (BEI) tahun 2012-2016. Hal ini berarti model dapat digunakan untuk analisa lebih lanjut atau dengan kata lain model dapat digunakan untuk memproyeksikan karena hasil goodness of fit-nya baik dengan nilai signifikansi $\mathrm{P}$ value 0,001 .

Mengetahui dan mengukur kemampuan model dalam menerangkan variasi variabel independen digunakan koefisien determinasi $\left(\mathrm{R}^{2}\right)$. Peneliti menggunakan nilai adjusted $\mathrm{R}^{2}$ pada saat mengevaluasi yang mana model regresi terbaik, karena tidak seperti $\mathrm{R}^{2}$, nilai adjusted $\mathrm{R}^{2}$ (koefisien determinasi yang telah disesuaikan) dapat naik atau turun apabila satu variabel independen ditambahkan ke dalam model.

Tabel 5.

Uji Koefisien Determinasi

\begin{tabular}{|c|c|c|c|c|}
\hline Model & $\mathrm{R}$ & R Square & $\begin{array}{l}\text { Adjusted R } \\
\text { Square }\end{array}$ & $\begin{array}{l}\text { Std. Error of the } \\
\text { Estimate }\end{array}$ \\
\hline & $0,301^{\mathrm{a}}$ & 0,091 & 0,075 & 0,5287 \\
\hline
\end{tabular}

Sumber: Data diolah, 2018

Hasil uji koefisien determinasi dalam Tabel 5 menunjukkan besarnya nilai adjusted $\mathrm{R}^{2}$ adalah sebesar 0,075 . Ini berarti variasi nilai perusahaan dapat dipengaruhi secara signifikan oleh variabel kinerja lingkungan, GCG dan variabel 
interaksi antara GCG dengan kinerja lingkungan sebesar 7,5 persen sedangkan sisanya sebesar 92,5 persen dijelaskan oleh faktor-faktor lain.

Hipotesis pertama di dalam penelitian ini adalah kinerja lingkungan berpengaruh positif pada nilai perusahaan. Semakin baik kinerja lingkungan yang dilakukan perusahaan maka citra perusahaan semakin baik dan kepercayaan masyarakat akan meningkat. Kinerja Lingkungan merupakan bentuk pertanggungjawaban perusahaan didalam mengelola lingkungannya. Hal ini bertujuan untuk mengurangi dampak negatif yang ditimbulkan akibat adanya aktivitas yang dijalankan perusahaan. Pengelolaan lingkungan yang baik akan berdampak terhadap keberlangsungan perusahaan. Investor akan tertarik berinvestasi pada perusahaan yang memiliki tanggung jawab terhadap lingkungan yang baik dan memiliki legitimasi masyarakat dapat mempengaruhi keberlangsungan perusahaan untuk kedepannya sehingga kinerja lingkungan berpengaruh terhadap nilai perusahaan

Hasil penelitian ini sesuai dengan penelitian yang dilakukan oleh (Matsumura et al., 2005), (Suratno et al., 2006), (Al-Tuwaijri, Christensen, \&Hughes, 2003), (Bidhari, Salim, \& Aisjah, 2013), (Hariati \& Rihatiningtyas, 2015), (Arieftiara \& Venusita, 2017), menyatakan bahwa kinerja lingkungan berpengaruh positif pada nilai perusahaan. Penemuan tersebut didukung adanya teori legitimasi, yaitu apabila perusahaan manufaktur mampu memperhatikan pengelolaan lingkungannya, maka keberadaan perusahaan yang memiliki citra yang bagus akan direspon positif oleh masyarakat. Investor lebih berminat pada perusahaan yang memiliki citra yang baik di masyarakat, karena berdampak pada 
tingginya loyalitas konsumen terhadap produk perusahaan. Dengan demikian, dalam jangka panjang penjualan dan profitabilitas perusahaan akan meningkat. Semakin tinggi profitabilitas perusahaan, maka semakin besar pula return yang diterima sehingga akan berdampak pada peningkatan nilai perusahaan. Bagi perusahaan yang taat dalam melakukan pengelolaan lingkungan juga merupakan salah satu faktor yang mendorong investor untuk berinvestasi pada perusahaan dengan kinerja lingkungan yang baik, sehingga berdampak pada peningkatan nilai perusahaan.

Hipotesis kedua dalam penelitian ini adalah Good Corporate Governance memperkuat pengaruh kinerja lingkungan pada nilai perusahaan. GCG yang diproksikan sebagai dewan komisaris independen yang diukur dengan cara membandingkan jumlah anggota dewan komisaris independen dan seluruh anggota komisaris dalam perusahaan.

Keberadaan dewan komisaris independen dapat memperkuat hubungan antara pengaruh kinerja lingkungan pada nilai perusahaan, karena fungsi monitoring oleh dewan komisaris independen terhadap berbagai kebijakan yang diambil manajemen terkait kepedulian terhadap lingkungan. Pengawasan oleh dewan komisaris independen memberikan nilai tambah bagi suatu perusahaan dan dapat memastikan bahwa manajemen benar-benar bekerja demi meningkatkan kinerja perusahaan. Peningkatan kinerja di dalam suatu perusahaan akan meningkatkan nilai perusahaan tersebut.

Penelitian ini sejalan dengan penelitian yang dilakukan oleh (Hariati \& Rihatiningtyas, 2015), Dewi dan Wirasedana (2017) yang menyatakan bahwa 
Keberadaan dewan komisaris dalam perusahaan dapat memberikan konstribusi yang efektif dalam proses penyusunan laporan keuangan yang berkualitas. Selain itu, dalam menjalankan tugas dan tanggung jawab dewan komisaris independen dianggap mampu menjaga sikap keindenpendensinya yang tidak terbatas pada pemegang saham mayoritas tetapi juga pemegang saham baik mayoritas maupun asing.

\section{SIMPULAN}

Kinerja Lingkungan berpengaruh positif pada nilai perusahaan. Hal ini berarti semakin bagus atau baik kinerja lingkungan yang dilakukan perusahaan akan dapat menarik para investor untuk berinvestasi karena telah mendapatkan kepercayaan dari masyarakat sehingga hal ini dapat meningkatkan nilai perusahaan.

Good Corporate Governanceyang diproksikan sebagai dewan komisaris independen memperkuat pengaruh kinerja lingkungan padanilai perusahaan. Hal ini berarti semakin tinggi proporsi dewan komisaris independen maka semakin ketat monitoring yang dilakukan dewan komisaris independen dalam meningkatkan kinerja perusahaan. Sehingga hal ini dapat meningkatkan nilai perusahaan.

Diharapkan perusahaan agar selalu bertanggung jawab dalam mengelola lingkungan dengan baik dan menjaga keberadaan dewan komisaris independen dalam mengawasi kegiatan operasionalnya sehingga meningkatkan kinerja perusahaan yang berpengaruh terhadap nilai perusahaan di mata investor. 
Penelitian selanjutnya disarankan untuk menggunakan semua perusahaan yang terdaftar di BEI yang ikut dalam program PROPER sehingga sampel lebih representative dan dapat menggambarkan kondisi kinerja lingkungan yang sesungguhnya.

Dilihat dari besarnya nilai adjusted $\mathrm{R}^{2}$ adalah sebesar 7,5 persen dipengaruhi oleh kinerja lingkungan, GCG dan variabel interaksi antara GCG dengan kinerja lingkungan sedangkan sisanya sebesar 92,5 persen dijelaskan oleh faktor-faktor lain. Penelitian selanjutnya disarankan menggunakan faktor-faktor lain misalnya kepemilikan manajerial, kepemilikan institusional dan komite audit karena dalam penelitian ini proksi mekanisme GCG yang digunakan hanya menggunakan dewan komisaris independen.

\section{REFERENSI}

Al-Najjar, S. M., \& Kalaf, K. H. (2012). Designing a Balanced Scorecard to Measure a Bank' s Performance : A Case Study. International Journal of Business Administraion, 3(4), 44-53.

Al-Tuwaijri, S. A., Christensen, T. E., \& Hughes, K. E. (2003). The Relation Among Enviromental Disclusure, Enviromental Performance, and Executive Committee Characteristics on Firm Performance in Oman: An Empirical Study. Asian Social Science, 10(11), 149-171.

Amanti, L. (2012). Pengaruh Good Corporate Governance Terhadap Nilai Perusahaan dengan Pengungkapan Corporate Sosial Responsibility sebagai Variabel Pemoderasi (Studi Kasus Pada Perusahaan Rokok Yang Terdaftar Di BEI). Jurnal Akuntansi UNESA, 8(1), 1-21.

Ardila, I. (2017). Pengaruh profitabilitas dan kinerja lingkungan terhadap nilai perusahaan. Jurnal Riset Finansial Bisnis, 1(1), 21-30.

Arieftiara, D., \& Venusita, L. (2017). Pengaruh Kinerja Lingkungan dan Intensitas Persaingan terhadap Nilai Perusahaan dalam rangka Mendukung Sustainability Development Goals. Jurnal Tekun, 9(1), 1-21. 
Barus, C. A., \& Setiawati, K. (2015). Pengaruh Asimetri Informasi, Mekanisme Corporate Governance, dan Beban Pajak Tangguhan Terhadap Manajemen Laba. Jurnal Wira Ekonomi Mikroskil, 5(1), 31-40.

Bidhari, S. C., Salim, U., \& Aisjah, S. (2013). Effect of Corporate Social Responsibility Information Disclosure on Financial Performance and Firm Value in Banking Industry Listed at Indonesia Stock Exchange. European Journal of Business and Management, 5(18), 39-47.

Birjandi, H., \& Sadeghi, M. M. M. (2015). The study effect agency theory and signaling theory on the level of voluntary disclosure of listed companies in Tehran Stock Exchange. Journal of Finance and Accounting, 6(1), 174-184.

Budiharjo, R. (2016). Pengaruh Good Corporate Governance Terhadap Return Saham dengan Profitabilitas sebagai Variabel Intervening dan Moderating. Jurnal Tekun, 7(1), 80-98.

Cahyono, R. (2007). Dampak Limbah Cair PT Kertas Basuki Rachmat Banyuwangi terhadap Kesehatan Masyarakat. Simposium Nasional Akuntansi, 7(1).

Chung, K. H., \& Pruitt, S. W. (1994). A Simple Approximation's q. Financial Management, 23(3), 70-74.

Danarwati, Y. S. (2013). Tujuan Memaksimumkan Nilai Perusahaan. Journal Sekolah Tinggi Ilmu Administrasi, 13(2), 1-9.

Deegan, \& Unerman. (2006). Financial AccountingTheory. New York: McGrawHill Education.

Ernawati, E. (2010). Pengaruh Kinerja Keuangan Terhadap Nilai Perusahaan dengan Corporate Governance sebagai Variabel Pemoderasi. Simposium Nasional Akuntansi, 11(3), 1-23.

Figge, V. F., \& Hahn, T. (2004). Sustainable Value Added - Ein neues Maß des Nachhaltig- keitsbeitrags von Unternehmen am Beispiel der Henkel KGaA. Ecological Economics, 48(2), 126-141.

Hariati, I., \& Rihatiningtyas, yeney widya. (2015). Pengaruh Tata Kelola Perusahaan dan Kinerja Lingkungan Terhadap Nilai Perusahaan. Simposium Nasional Akuntansi, 18(1-16).

Hernadi, B. H. (2012). Green Accounting for Corporate Sustainability. Club of Economics in Miskolc, 8(2), 23-30. 
Komite Nasional Kebijakan Governance, (KNKG). (2006). Pedoman Umum Good Corporate Governance Indonesia.

Matsumura, K., Yuriko, N., Nakano, M., Amano, A., Kokubu, K., \& Gemba, K. (2005). Corporate Environmental and Financial Performances and the Effects of Informational Instruments of Environmental Policy in Japan. IGES Kasnsai Research Center Dissucion Paper, 5(1), 1-23.

Pflieger, J., Fischer, M., Kupfer, T., \& Eyerer, P. (2015). The contribution of life cycle assesment to global sustainability reporting of organizations. Management of Environmental, 16(2), 1-16.

Prastuti, N. K. K., \& Budiasih, I. G. N. B. (2015). Pengaruh Good Corperate Governance pada Nilai Perusahaan dengan Moderasi Corporate Social Responsibility. E-Jurnal Akuntansi Universitas Udayana, 13(1), 114-129.

Sawitri, A. P. (2017). Analisis Pengaruh Pengungkapan Lingkungan dan Kinerja Lingkungan terhadap Nilai Perusahaan. Jurnal Akuntansi : Riset Dan Artikel Akuntansi, 10(1), 177-187.

Sumarsono, S. R. (2004). Akuntansi Suatu Pengantar. Jakarta: Salemba Empat.

Suratno, I. B., Darsono, \& Mutmainah, S. (2006). Pengaruh Enviromental performance terhadapenviromental disclousure dan ekonomic performance. Simposium Nasional Akuntansi, 9(1), 23-26.

Sutopoyudo. (2009). Pengaruh Penerapan Corporate Social Responsibility (CSR) Terhadap Profitabilitas Perusahaan. Jurnal Akuntansi: Riset Dan Artikel Akuntansi, 9(2), 1-23. 